\title{
Chemical composition, anti-oxidative activity and in vitro dry matter degradability of Kinnow mandarin fruit waste
}

\author{
Ravleen Kour ${ }^{1}$, Ankur Rastogi ${ }^{1}$, R. K. Sharma ${ }^{1}$, Arvind Kumar ${ }^{2}$ and Pratiksha Raghuwanshi ${ }^{3}$
}

1. Division of Animal Nutrition, Faculty of Veterinary Sciences and Animal Husbandry, Sher-e-Kashmir University Agriculture Sciences and Technology of Jammu, R S Pura, Jammu, Jammu and Kashmir, India; 2. Division of Livestock Products Technology, Faculty of Veterinary Sciences and Animal Husbandry, Sher-e-Kashmir University Agriculture Sciences and Technology of Jammu, R S Pura, Jammu, Jammu and Kashmir, India; 3. Division of Veterinary Physiology and Biochemistry, Faculty of Veterinary Sciences and Animal Husbandry, Sher-e-Kashmir University Agriculture Sciences and Technology of Jammu, R S Pura, Jammu, Jammu and Kashmir, India.

Corresponding author: Ankur Rastogi, e-mail: dr_ankur76@rediffmail.com, RK: dr.ravkour@gmail.com, RKS: rksann@rediffmail.com, AK: drarvindlpt̄@gmail.com, PR: pratiksha.rastogi@gmail.com

Received: 16-06-2014, Revised: 02-09-2014, Accepted: 09-09-2014, Published online: 12-10-2014

doi: 10.14202/vetworld.2014.803-806. How to cite this article: Kour R, Rastogi A, Sharma RK, Kumar A, Raghuwanshi P (2014) Chemical composition, anti-oxidative activity and in vitro dry matter degradability of Kinnow mandarin fruit waste, Veterinary World 7(10): 803-806.

\begin{abstract}
Aim: Fruit processing and consumption yield a significant amount of by-products as waste, which can be used as potential nutrient suppliers for livestock. "Kinnow" (Citrus nobilis Lour x Citrus deliciosa Tenora) is one of the most important citrus fruit crops of North Indian States. Its residues are rich in carbohydrates but poor in protein and account for approximately 55-60\% of the raw weight of the fruit. Present study assessed the chemical composition and anti-oxidative activity of Kinnow mandarin fruit waste (KMW) and scrutinized the impact of dietary incorporation of variable levels of KMW on in vitro dry matter digestibility (IVDMD).
\end{abstract}

Materials and Methods: Sun dried and ground KMW was analyzed for proximate composition, fibre fractions and calcium and phosphorus content. Antioxidant potential of KMW as total phenolic count and 1-diphenyl-2-picrylhydrazyl (DPPH) scavenging activity was assayed in an alcoholic extract of KMW. The effect of inclusion of KMW at variable levels (0-40\%) in the isonitrogenous concentrate mixtures on in vitro degradability of composite feed (concentrate mixture:Wheat straw; 40:60) was also carried out.

Results: KMW after sun-drying contained $92.05 \%$ dry matter. The crude protein content of $7.60 \%$ indicates it being marginal in protein content, whereas nitrogen free extract content of $73.69 \%$ suggests that it is primarily a carbonaceous feedstuff. This observation was also supported by low neutral detergent fiber and acid detergent fiber content of $26.35 \%$ and $19.50 \%$, respectively. High calcium content (0.92\%) vis-à-vis low phosphorus content (0.08\%), resulted in wide Ca:P ratio (11.5) in KMW. High anti-oxidative potential of KMW is indicated by total phenolic content values of $17.1 \pm 1.04 \mathrm{mg}$ gallic acid equivalents/g and DPPH free radicle scavenging activity $96.2 \mu \mathrm{g} / \mathrm{ml}$ (effective concentration 50). Mean IVDMD\% of all the composite rations was found to be comparable ( $>0.05$ ) irrespective of the level of KMW inclusion, indicating no negative effect of KMW inclusion on in vitro nutrient utilization.

Conclusion: KMW is a carbonaceous feedstuff and may be incorporated in ruminant ration up to the level of $40 \%$ (w/w basis) without affecting in vitro degradability.

Keywords: antioxidant, in vitro dry matter digestibility, Kinnow mandarin waste, unconventional feedstuff.

\section{I ntroduction}

Fruit production and consumption has seen tremendous growth in last few years. The area under fruit cultivation in India is 6.98 million hectares with a total production of 81.28 million tonnes [1]. Processing and consumption of fruits yield a significant amount of by-products as waste. It has been demonstrated that these fruit by-products can be potential nutrient suppliers especially energy for livestock [2]. These are available free of cost, are rich in micro-nutrients and can positively affect livestock health due to their high anti-oxidative activity. Livestock feeding regimen based on these by-products also offers two important advantages;

Copyright: The authors. This article is an open access article licensed under the terms of the Creative Commons Attributin License (http:// creative commons.org/licenses/by/2.0) which permits unrestricted use, distribution and reproduction in any medium, provided the work is properly cited. it helps in diminishing dependence of livestock on grains and eliminates the need for costly waste management programs [3].

Citrus fruits are principally consumed by humans as fresh fruit or processed juice. After juice is extracted from the fruit, there remains a residue comprised of peel (flavedo and albedo), pulp (juice sac residue), rag (membranes and cores) and seeds. These components, either individually or in various combinations, are available for utilization as ruminant feedstuffs [4].

"Kinnow," a hybrid between King and willow mandarins (Citrus nobilis Lour x Citrus deliciosa Tenora) is one of the most important citrus fruit crops in North Indian States [5]. Jammu and Kashmir produces 20,810 MT of citrus fruit [1], majority of which is produced in Jammu division and out of which a considerable share is that of Kinnow mandarins. Kinnow 
residues are rich in carbohydrates but poor in protein and account for approximately $55-60 \%$ of the weight of the raw fruit [6].

Present study was conducted to assess the chemical composition and anti-oxidative activity of Kinnow mandarin fruit waste (KMW) and to scrutinize the impact of dietary incorporation of variable levels of KMW on in vitro dry matter digestibility (IVDMD).

\section{Materials and Methods}

\section{Study material}

KMW was collected from local juice vendors of Jammu city and nearby areas in the evening. Immediately after collection in plastic buckets, KMW was brought to the laboratory and sun dried by spreading out on polythene sheets and was frequently turned around to ensure quick and uniform drying. After about $16 \mathrm{~h}$ of sun-drying, waste was pulverized through a laboratory grinder to form a coarse powder.

\section{Procedures}

Proximate analysis and calcium and phosphorus content estimation of pulverized KMW sample was done as per [7], whereas fiber fractions (neutral detergent fiber [NDF] and acid detergent fiber [ADF]) were analyzed as per [8].

Antioxidant potential of KMW was assayed in an alcoholic extract of KMW. Extract was prepared by refluxing $10 \mathrm{~g}$ of dried and ground KMW with $100 \mathrm{ml}$ of $70 \%$ ethanol at $72^{\circ} \mathrm{C}$ for $121 \mathrm{~min}$. The extract was filtered through Whatman No.4 filter paper and was re-dissolved in the appropriate amount of $70 \%$ ethanol to get the final concentration of $5.0 \mathrm{mg} / \mathrm{ml}$.

Total phenolic content (TPC) in the prepared KMW extract was determined using the FolinCiocalteu reagent [9]. Result was expressed as milligram gallic acid equivalents per gram fresh weight (mg GAE/g). The ability of KMW extract to scavenge the 1-diphenyl-2-picrylhydrazyl (DPPH) (2,2-diphenyl-1-picryl-hydrazylhydrate) free radical was measured [10]. DPPH solution (40 mg/L) was prepared by dissolving DPPH in 100\% methanol. KMW extract was then added to $3 \mathrm{ml}$ of the DPPH solution, and the absorbance was determined at $515 \mathrm{~nm}$ after $10,30,60$, and $120 \mathrm{~min}$.

The effect of inclusion of KMW at variable levels $(0-40 \%)$ in the isonitrogenous concentrate mixtures on in vitro degradability of composite feed (concentrate mixture:Wheat straw; 40:60) was carried out [11]. Ingredient composition of different iso-nitrogenous concentrate mixtures formulated for in vitro study along with the percent in vitro IVDMD is detailed in Table-1.

\section{Statistical analysis}

Statistical analysis of the data generated was performed using a personal computer. Generalized linear model analysis of variance for data generated by in vitro trial and one-way analysis of variance for chemical composition data was conducted [12].

\section{Results}

The proximate composition and fiber fractions of KMW used in this study are shown in Table-2.

KMW after sun-drying contained 92.05\% dry matter (DM). On DM basis, KMW contained 7.60\% crude protein (CP) and $73.69 \%$ nitrogen free extract (NFE) along with NDF and ADF content of $26.35 \%$ and $19.50 \%$, respectively.

The TPC was found to be $17.1 \pm 1.04 \mathrm{mg}$ GAE/g of KMW, whereas the DPPH free radicle scavenging activity of KMW was determined as median effective concentration 50 and was found to be $96.2 \mu \mathrm{g} / \mathrm{ml}$.

In vitro DM digestibility of composite diet containing variable levels of KMW in iso-nitrogenous concentrate mixtures are shown in Table- 1 . The mean IVDMD\% of all the composite rations was found to be comparable $(p>0.05)$ irrespective of the level of KMW inclusion. The percent IVDMD of ration containing $40 \% \mathrm{KMW}(\mathrm{w} / \mathrm{w})$ in concentrate mixture

Table-1: In vitro dry matter digestibility of composite ration comprising of variable levels of KMW.

\begin{tabular}{|c|c|}
\hline $\begin{array}{l}\text { I so-nitrogenous rations containing } \\
\text { variable levels of } \mathrm{KMW}^{1}\end{array}$ & $\begin{array}{l}\text { I VDMD } \\
(\%)\end{array}$ \\
\hline $\begin{array}{l}\text { Ration } 1 \text { (KMW 0\%, Maize 29.5\%, WB } \\
29.5 \% \text {, MOC 38\%, MM } 2 \% \text {, Salt } 1 \% \text { ) }\end{array}$ & $52.99 \pm 2.66$ \\
\hline $\begin{array}{l}\text { Ration } 2 \text { (KMW } 10 \% \text {, Maize } 24.0 \% \text {, WB } \\
24.0 \% \text {, MOC } 39 \% \text {, MM } 2 \% \text {, Salt } 1 \% \text { ) }\end{array}$ & $52.74 \pm 2.66$ \\
\hline $\begin{array}{l}\text { Ration } 3 \text { (KMW 15\%, Maize } 21.0 \% \text {, WB } \\
21.0 \% \text {, MOC } 40 \% \text {, MM } 2 \% \text {, Salt } 1 \% \text { ) }\end{array}$ & $52.96 \pm 1.70$ \\
\hline $\begin{array}{l}\text { Ration } 4 \text { (KMW } 20 \% \text {, Maize } 18.0 \% \text {, WB } \\
18.0 \% \text {, MOC } 41 \% \text {, MM } 2 \% \text {, Salt } 1 \% \text { ) }\end{array}$ & $52.66 \pm 1.99$ \\
\hline $\begin{array}{l}\text { Ration } 5 \text { (KMW } 25 \% \text {, Maize } 15.5 \% \text {, WB } \\
15.5 \% \text {, MOC } 41 \% \text {, MM } 2 \% \text {, Salt } 1 \% \text { ) }\end{array}$ & 51.44 \\
\hline $\begin{array}{l}\text { Ration } 6 \text { (KMW } 30 \% \text {, Maize } 13.0 \% \text {, WB } \\
13.0 \% \text {, MOC } 41 \% \text {, MM } 2 \% \text {, Salt } 1 \% \text { ) }\end{array}$ & $54.24 \pm 2.69$ \\
\hline $\begin{array}{l}\text { Ration } 7 \text { (KMW-35\%, Maize } 10.0 \% \text {, WB } \\
10.0 \% \text {, MOC } 42 \% \text {, MM } 2 \% \text {, Salt } 1 \% \text { ) }\end{array}$ & $53.96 \pm 2.72$ \\
\hline $\begin{array}{l}\text { Ration } 8 \text { (KMW-40\%, Maize } 7.0 \% \text {, WB } \\
7.0 \% \text {, MOC } 43 \% \text {, MM } 2 \% \text {, Salt } 1 \%)\end{array}$ & $50.37 \pm 3.52$ \\
\hline
\end{tabular}

${ }^{1}$ All rations were incubated in rumen liquor along with wheat straw in 40:60 proportion. $\mathrm{KMW}=$ Kinnow mandarin waste; $\mathrm{WB}=$ Wheat bran, $\mathrm{MOC}=$ Mustard oil cake, $\mathrm{MM}=$ Mineral mixture

Table-2: Chemical composition of KMW.

\begin{tabular}{lc}
\hline Attribute & Percentage* \\
\hline Moisture & $92.05 \pm 3.71$ \\
OM & $95.77 \pm 3.94$ \\
CP & $7.60 \pm 0.07$ \\
EE & $3.57 \pm 0.01$ \\
CF & $10.92 \pm 0.46$ \\
Total ash & $4.23 \pm 0.37$ \\
AlA & $0.50 \pm 0.01$ \\
NFE & $73.69 \pm 1.34$ \\
NDF & $26.35 \pm 2.68$ \\
ADF & $19.50 \pm 2.01$ \\
Calcium & $0.92 \pm 0.01$ \\
Phosphorus & $0.08 \pm 0.001$
\end{tabular}

*All values except moisture are expressed on DM basis. $\mathrm{DM}=$ Dry matter, $\mathrm{OM}=$ Organic matter, $\mathrm{CP}=$ Crude protein, $\mathrm{EE}=$ Ether extract, $\mathrm{CF}=$ Crude fibre, $\mathrm{AI} A=\mathrm{Acid}$ insoluble ash, $\mathrm{NFE}=$ Nitrogen free extract, NDF=Neutral detergent fiber, $\mathrm{ADF}=$ Acid detergent fiber, $\mathrm{KMW}=$ Kinnow mandarin waste 
was $50.37 \pm 3.52$, which was similar $(p>0.05)$ to that $(52.99 \pm 2.66)$ of the ration having conventional concentrate $(0 \% \mathrm{KMW})$.

\section{Discussion}

High moisture content of citrus waste has always restricted their use as feedstuff [4]. Moisture content of $<10 \%$ achieved after sun-drying for $16 \mathrm{~h}$ in this study indicate that this method and duration is sufficient to dry KMW for further processing and storage, although frequent turning is essential to achieve this level of drying.

The CP content of $7.60 \%$ indicate it being marginal in protein content, whereas NFE content of $73.69 \%$ suggests that it is primarily a carbonaceous feedstuff and based on the composition, it can be considered as a replacement candidate for starchy feedstuffs used in conventional ration. This observation was also supported by low NDF and ADF content. High calcium content (0.92\%) vis-à-vis low phosphorus content $(0.08 \%)$, resulted in wide Ca:P ratio (11.5) in KMW. This finding is similar to the observations from other citrus fruit wastes [4]. This wide calcium: Phosphorus ratio needs to be corrected by using phosphorus supplements while formulating the practical rations.

The chemical composition analytical data relevant to animal nutrition and pertaining to KMW is scanty in the referred literature. The proximate composition and fiber fractions values of KMW obtained in this study are in agreement with the values available for waste of other citrus fruits [13,14]. A comparative analysis with the cellulose (8.8\%), hemicellulose (4.4\%), lignin (3.7\%), protein (12.2\%) and ash (5.9\%) content of dried Kinnow pulp [15] indicate that Kinnow pulp is having less ADF and NDF content and more crude protein and ash content as compared to Kinnow peel.

TPC values found in the present study are similar to the values previously reported for Kinnow peels [16]. Phenolics or polyphenols have received considerable attention for their physiological function, including antioxidant, anti-mutagenic and anti-tumour activities. These are believed to account for a major portion of the antioxidant activity in many plants. A linear correlation between phenolic content and antioxidant ability in fruits and vegetables has been demonstrated [17], however in contrast, it has also been reported that Kinnow peel extract with lower TPC in comparison to extracts from litchi and grape residues exhibited higher free scavenging ability [16]. The TPC content of KMW was found to be higher than that reported for edible portions of other common fruits [18]. Similar observation was reported by Khalid et al. [19].

DPPH is a free radical, stable at room temperature, which produces a violet solution in ethanol. It is reduced in the presence of an antioxidant molecule, giving rise to uncoloured ethanol solutions. The use of DPPH provides an easy and rapid way to evaluate antioxidants [20]. The DPPH free radicle scavenging activity of KMW estimated in the present study indicate higher antioxidant activity than other common fruit residues like grape and litchi residues [16] and pomegranate peel [21].

The comparable mean IVDMD\% of all the composite rations irrespective of the level of KMW indicate that KMW inclusion does not hamper the nutrient degradability and its utilization is similar to that of other carbonaceous feedstuffs (maize and wheat bran [WB]). Similar observations were reported [22,23] in studies on in vitro fermentation of another citrus pulp. It has been suggested that supplementation of forages with citrus fruit waste that are rich in pectin or highly degradable NDF usually has a less negative effect on the rumen environment, and thus on cellulolytic activity, than supplementation with starch-or sugar-rich feeds [4,24]. When citrus fruit waste substitutes for starchy feeds, DM digestibility remains unaffected $[25,26]$. This is in agreement with the findings of the present study, where the isonitrogenous concentrate mixtures tested for IVDMD were prepared mainly by replacement of maize and WB (starchy feedstuffs) from the conventional concentrate by KMW.

It is quite possible that even higher levels of KMW inclusion in concentrate mixture would not have impacted IVDMD values of composite ration; however, formulating a balanced diet in terms of calorie protein ratio would have become increasingly difficult with increasing levels of KMW.

\section{Conclusion}

KMW seems to be an ideal energy supplement for ruminants besides providing beneficial effects over the health as evident by high anti-oxidative potential. As per the results of present study, $40 \%$ inclusion level of KMW in concentrate mixture seems to be appropriate under in vitro trial; however, in vivo feeding trials are required to validate the in vitro results.

\section{Authors' Contributions}

$\mathrm{AR}$ and RKS designed the research program. RK conducted the research work. AK and PR helped in conducting laboratory analysis. All authors contributed in the preparation of the manuscript. AR revised the manuscript. All authors read and approved the final manuscript.

\section{Acknowledgements}

Authors are grateful to Dean, FVSc and AH, Director Education and Vice Chancellor of SKUASTJammu for providing necessary funds and facilities for carrying out the research work presented in this paper.

\section{Competing I nterests}

The authors declare that they have no competing interests. 


\section{References}

1. NHB. (2014) Indian Horticulture Database 2013. National Horticulture Board, Gurgaon, India.

2. FAO, Wadhwa, M. and Bakshi M.P.S. (2013) Utilization of Fruit and Vegetable Wastes as Livestock Feed and as Substrates for Generation of other Value-Added Products. Food and Agriculture Organization, Rome, Italy.

3. Grasser, L.A., Fadel, J.G., Garnett, I. and De Peters, E.J. (1995) Quantity and economic importance of nine selected by products used in California dairy rations. J. Dairy Sci., 78: 962-971.

4. Bampidis, V.A. and Robinson, P.H. (2006) Citrus by-products as ruminant feeds: A review. Anim. Feed. Sci. Tech., 128: $175-217$.

5. Sharma, S., Singh, B., Rani, G., Zaidi, A.A., Hallan, V., Nagpal, A. and Virik, G.S. (2007) In vitro production of Indian citrus ringspot virus (ICRSV) free Kinnow plants employing phyto-therapy coupled with shoot tip grafting. In Vitro. Cell. Dev-Plant., 43: 254-259.

6. Kalra, K.L., Grewal, H.S. and Kahlon, S.S. (1989) Bioconversion of Kinnow-mandarin waste into single-cell protein. Mircen J. Appl. Microb., 5: 321-326.

7. AOAC. (2012) Official Methods of Analysis. $19^{\text {th }}$ ed., Vol. I. Association of Official Analytical Chemists, Washington, D.C.

8. Van Soest, P.J., Robertson, J.B. and Lewis, B.A. (1991) Methods for dietary fiber and nonstarch polysaccharides in relation to animal nutrition. J. Dairy Sci., 74: 3583-3597.

9. Isabelle, M., Lee, B.L., Ong, C.N., Liu, X. and Huang, D. (2008) Peroxyl radical scavenging capacity, polyphenolics, and lipophilic antioxidant profiles of mulberry fruits cultivated in Southern China. J. Agric. Food Chem., 56(20): 9410-9416.

10. Erel, O. (2004) A novel automated direct measurement method for total antioxidant capacity using a new generation, more stable DPPH radical cation. Clin. Biochem., 37: $277-285$.

11. Tilley, J.M.A. and Terry, R.A. (1963) A two stage technique for the in vitro digestion of forage crops. J. Br. Grassl. Soc., 18: 104-111.

12. Snedecor, G.W. and Cochran, W.G. (1994) Statistical Methods. $8^{\text {th }}$ ed. East West Press Private Limited, New Delhi.

13. Broderick, G.A., Mertens, D.R. and Simons, R. (2002) Efficacy of carbohydrate sources for milk production by cows fed diets based on alfalfa silage. J. Dairy Sci., 85: 1767-1776.

14. Hall, M.B. (2003) Feeding sugar to ruminants. In: Proceedings of the Third National Symposium on
Alternative Feeds for Livestock and Poultry, Kansas City, MO, USA. p65-76.

15. Oberoi, H.S., Chavan, Y., Bansal, S. and Dhillon, G.S. (2010) Production of cellulases through solid state fermentation using Kinnow pulp as a major substrate. Food Bioprocess Technol., 3: 528-536.

16. Babbar, N., Oberoi, H.S., Uppal, D.S. and Patil, R.T. (2011) Total phenolic content and antioxidant capacity of extracts obtained from six important fruit residues. Food Res. Int., 44: 391-396.

17. Kaur, C. and Kapoor, H.C. (2000) Antioxidant activity and total phenolic content of some Asian vegetables. Int. J. Food Sci. Technol., 37: 153-161.

18. Isabelle, M., Lee, B.L., Lim, M.T., Koh, W.P., Huang, D. and Ong, C.N. (2010) Antioxidant activity and profiles of common fruits in Singapore. Food Chem., 123: 77-84.

19. Khalid, M.S., Malik, A.U., Khalid, S., Hafez, O. and Amin, M. (2013) Kinnow mandarin: The premier citrus of Pakistan, Agriculture Information Bank. Available from: http://www agrinfobank.wordpress.com/2013/05/13/ kinnow-mandarin-the-premier-citrus-of-pakistan/.[Last accessed 2014 Jun 14].

20. Mensor, L.L., Menezes, F.S., Leitão, G.G., Reis, A.S., Santos, T.C., Coube, C.S. and Leitão, S.G. (2001) Screening of Brazilian plant extracts for antioxidant activity by the use of DPPH free radical method. Phytother. Res., 15: 127-130.

21. Devatkal, S., Narsaiah, K. and Borah, A. (2010) Antioxidant effect of extracts of Kinnow rind, pomegranate rind and seed powders in cooked goat meat patties, Meat. Sci., 85: 155-159.

22. Sunvold, G.D., Hussein, H.S., Fahey Jr., G.C., Merchen, N.R. and Reinhart, G.A. (1995) In vitro fermentation of cellulose, beet pulp, citrus pulp, and citrus pectin using fecal inoculum from cats, dogs, horses, humans, and pigs and ruminal fluid from cattle. J. Anim. Sci., 73: 3639-3648.

23. Brown, W.F. and Johnson, D.D. (1991) Effects of energy and protein supplementation of ammoniated tropical grass hay on the growth and carcass characteristics of cull cows. J. Anim. Sci., 69: 348-357.

24. Barrios-Urdaneta, A., Fondevila, M. and Castrillo, C. (2003) Effect of supplementation with different proportions of barley grain or citrus pulp on the digestive utilization of ammonia-treated straw by sheep. Anim. Sci., 76: 309-317.

25. Bhattacharya, A.N. and Harb, M. (1973) Dried citrus pulp as a grain replacement for awasi lambs. J. Anim. Sci., 36: $1175-1180$.

26. Martınez-Pascual, J. and Fernandez-Carmona, J. (1980) Citrus pulp in diets for fattening lambs. Anim. Feed Sci. Technol., 5: 11-22. 